\title{
Perancangan Ulang Tata Letak Fasilitas Menggunakan Metode Systematic Layout Planning Pada PT Pilar Kekar Plasindo
}

\author{
Lulu Elvira ${ }^{1}$, Bambang Suhardi ${ }^{* 2}$, Rahmaniyah Dwi Astuti ${ }^{3}$ \\ ${ }^{1,2,3}$ Program Studi Teknik Industri, Fakultas Teknik, Universitas Sebelas Maret, Jalan Ir \\ Sutami 36 A, Kentingan, Jebres, Surakarta, 57126, Indonesia \\ e-mail: ${ }^{1}$ luluelvira11@gmail.com, ${ }^{* 2}$ bambangsuhardi@ staff.uns.ac.id, ${ }^{3}$ niyah22@gmail.com
}

(artikel diterima: 29-06-2020, artikel disetujui: 27-11-2020)

\begin{abstract}
Abstrak
Peralatan dan desain produk yang baik tidak akan berarti jika tidak terdapat perencanaan tata letak fasilitas yang baik. Masalah yang dimiliki oleh PT. Pilar Kekar Plasindo terjadi pada bagian produksi polyethylene kecil. Masalah tersebut disebabkan oleh produksi polyethylene kecil yang memiliki jarak transfer total material yang besar. Masalahmasalah yang terjadi pada produksi polyethylene kecil yaitu jarak antar stasiun, cross movement, back tracking, dan mesin-mesin rusak yang masih ditempatkan di bagian produksi. Kondisi tersebut membuat biaya penanganan material dan jarak menjadi besar. Penelitian ini bertujuan untuk menghasilkan desain tata letak fasilitas produksi yang dapat meminimalkan jarak dan biaya perpindahan material. Metode yang digunakan adalah Systematic Layout Planning (SLP). Pada penelitian ini tiga desain alternatif dibandingkan dan usulan tata letak fasilitas kedua terpilih karena mampu mengurangi total biaya transfer material sebesar 68,2\% dan mengurangi jarak transfer material sebesar 59,6\% dari tata letak fasilitas awal.
\end{abstract}

Kata kunci: Activity Relationship Chart, Activity Relationship Diagram, biaya, penangan material, Systematic Layout Planning

\begin{abstract}
Good equipment and product design are meaningless if there is no good layout planning. Problems faced by PT. Pilar Kekar Plasindo occurs in the production of small polyethylene. This is because small polyethylene production has large material total transfer distance. Small polyethylene problems, namely the distance between stations, cross movement, back tracking, and the broken machine that is still placed in the production section. This makes the material handling costs and distances become large. So this research aims to produce a layout design of production facilities that can minimize the distance and cost of material movement. The method used is Systematic Layout Planning $(S L P)$. Three alternative designs were compared, and the second proposed facility layout was chosen because it was able to reduce the total cost of material transfer by $68.3 \%$ and reduce the distance of material transfer by $59.6 \%$ from the initial facility layout.
\end{abstract}

Keywords: Activity Relationship Chart, Activity Relationship Diagram, cost, material handling , Systematic Layout Planning

\section{PENDAHULUAN}

Permasalahan tata letak fasilitas sering dijumpai pada banyak industri, seperti adanya aliran bolak-balik (back tracking) dan aliran perpindahan bahan yang 
berpotongan (cross movement). Permasalahan ini terjadi karena tata letak pabrik yang tidak teratur. Pangestika, Handayani dan Kholil (2016) menyatakan perancangan tata letak fasilitas merupakan hal penting untuk meningkatkan produktivitas perusahaan. Perancangan tata letak fasilitas yang kurang terencana dan jarak perpindahaan material yang cukup jauh dapat menimbulkan sejumlah masalah seperti penurunan produksi dan peningkatan biaya yang harus dikeluarkan (Muslim and Ilmaniati, 2018). Tata letak yang baik adalah tata letak yang dapat menangani sistem material handling secara menyeluruh (Wignjosoebroto, 2003). Hal ini disebabkan karena proses perpindahan bahan mempengaruhi operational flow time sebesar 95\% (Starbek and Menart, 2000). Dengan adanya perancangan tata letak pabrik yang baik, maka gerakan bolak-balik (back tracking), jarak perpindahan material, dan biaya material handling dapat diminimumkan (Sofyan and Syarifuddin, 2015).

PT. Pilar Kekar Plasindo merupakan perusahaan yang memproduksi plastik jenis polyethylene. Tata letak fasilitas pada PT. Pilar Kekar Plasindo menggunakan jenis process layout. PT. Pilar Kekar Plasindo memiliki beberapa permasalahan yang terjadi pada produk polyethylene kecil, yaitu jarak yang berjauhan antara stasiun yang berhubungan, cross movement, dan back tracking. Jarak yang jauh antar stasiun dapat menyebabkan ongkos material handling menjadi besar dan waktu produksi menjadi lebih lama dikarenakan pekerja membutuhkan waktu yang cukup lama dalam pemindahan barang antar stasiun. Hal ini sesuai dengan Muslim dan Ilmaniati (2018) yang mengatakan perancangan tata letak antara departemen yang kurang terencana dan jarak perpindahaan material yang kurang baik dapat menimbulkan sejumlah masalah seperti penurunan produksi dan peningkatan biaya yang harus dikeluarkan. Sedangkan adanya cross movement dan back tracking mengakibatkan tidak baiknya aliran bahan dan meningkatkan total jarak material handling. Hal ini sesuai dengan Stephens (2010) yang menyatakan bahwa cross movement merupakan suatu masalah karena menyebabkan kemacetan aliran bahan dan risiko keselamatan. Sedangkan back tracking menyebabkan biaya produksi meningkat sebesar tiga kali lipat dibanding aliran produksi yang dilakukan secara tepat.

Berdasarkan masalah-masalah yang terdapat pada bagian produksi polyethylene kecil, maka perbaikan yang dapat dilakukan yaitu membuat rancangan tata letak fasilitas produksi yang dapat meminimalkan jarak dan biaya pada perpindahan bahan. Metode yang digunakan pada penelitian ini yaitu Systematic Layout Planning (SLP). SLP dapat menghasilkan rancangan tata letak fasilitas produksi yang dapat meminimumkan total ongkos material handling dan meminimumkan jarak antar ruang produksi, serta agar pola aliran material produksi dapat berjalan dengan lancar dan teratur (Pangestika, Handayani and Kholil, 2016). Selain itu, penggunaan metode SLP juga memiliki prosedur yang terperinci dalam merancang tata letak pabrik dan dapat memunculkan lebih dari satu alternatif (Muslim and Ilmaniati, 2018).

Penelitian sebelumnya di bidang ini dilakukan oleh Kustriyanto, Pambuditama dan Irawan (2016) yang menggunakan metode SLP dan blocplan. Menurut Tompkins et al. (2010), walaupun blocplan sama seperti SLP yang dapat menerima dan menggunakan Relationship chart dan From To chart, namun blocplan tidak dapat menggunakan keduanya pada waktu bersamaan. Blocplan juga memiliki kemungkinan tidak dapat menggambarkan tata letak awal secara akurat. Sedangkan penelitian Paillin (2013) menggunakan algoritma craft. Tompkins et al. (2010) mengatakan bahwa craft memiliki kelemahan, yaitu dapat mengalami error apabila 
departemen yang ditukar memiliki ukuran yang berbeda, sehingga perkiraan pada biaya material handling menjadi tidak akurat. Kelemahan lainnya yaitu hanya bisa menukarkan letak depatemen yang berdekatan. Penelitian lain yang menggunakan metode SLP juga dilakukan oleh Suhardi, Juwita dan Astuti (2019), namun diaplikasikan pada industri garmen dengan tipe aliran produksi yang lurus. Sedangkan dalam penelitian ini menggunakan metode SLP pada pabrik plastik dengan tipe aliran produksi circular. Adanya penelitian ini diharapkan dapat meningkatkan efisiensi dan produktivitas pada PT. Pilar Kekar Plasindo.

Penelitian ini dibagi menjadi beberapa bagian. Bagian 1 menguraikan terntang pendahuluan. Bagian 2 menguraikan tentang metode penelitian dan teknik pengumpulan data. Bagian 3 menguraikan hasil dan pembahasan, dan kesimpulan disajikan pada bagian 4 .

\section{METODE PENELITIAN}

Penelitian ini menggunakan metode Systematic Layout Planning (SLP). Naganingrum, Jauhari dan Herdiman (2013) menyatakan metode SLP terdiri dari tiga tahapan, yaitu tahap analisis, tahap penyesuaian, dan tahap evaluasi. Tahapan tersebut dimulai dari menganalisis aliran material, menganalisis kebutuhan area yang tersedia, tahap perencanaan diagram hubungan ruang, dan perancangan alternatif tata letak fasilitas. Tahap terakhir adalah melakukan pemilihan terhadap beberapa alternatif tata letak fasilitas yang telah dirancang.

Penelitian ini dilakukan dengan beberapa tahapan. Tahapan tersebut yaitu observasi langsung dan wawancara pada beberapa pekerja produksi dan nonproduksi di PT. Pilar Kekar Plasindo, sehingga dapat diketahui kondisi dan masalah yang ada pada perusahaan ini. Berdasarkan observasi langsung dan wawancara, diketahui bahwa perancangan tata letak pada produksi polyethylene kecil perlu dilakukan. Tahap selanjutnya adalah pengumpulan data yang terdiri dari data primer dan data sekunder. Data primer didapat dari hasil observasi langsung di lapangan seperti tata letak fasilitas awal perusahaan, luas area proses produksi yang tersedia, jumlah dan ukuran mesin, serta aliran material. Sedangkan data sekunder didapat dari perusahaan berupa data umum perusahaan, struktur organisasi, proses produksi, dan data pekerja. Tahap selanjutnya yaitu pengolahan data tata letak fasilitas awal dan perancangan tata letak fasilitas usulan.

\subsection{Pengolahan Data Tata Letak Fasilitas Awal}

Pengolahan data yang dilakukan dalam tata letak fasilitas awal menggunakan SLP, yaitu analisis aliran material yang terdiri dari penentuan frekuensi perpindahan material, penentuan jarak perpindahan bahan dengan metode Rectilinear menggunakan persamaan (1). Kemudian perhitungan ongkos material handling $(\mathrm{OMH})$ menggunakan persamaan (2), penentuan From To chart, Inflow menggunakan persamaan (3), dan tabel skala prioritas. Berikut adalah persamaanpersamaan pada pengolahan data tata letak fasilitas awal.

$d_{i j}=\left|x_{i}-x_{j}\right|+\left|y_{i}-y_{j}\right|$

Total $O M H=(O M H$ per meter $) x($ jarak transportasi) $x$ (frekuensi)

Inflow $=\frac{\text { Ongkos di mesin } A}{\text { Ongkos yang masuk ke mesin } A}$ 


\subsection{Perancangan Tata Letak Fasilitas Usulan}

Pengolahan data dengan SLP untuk menghasilkan rancangan tata letak fasilitas usulan terdiri dari penyesuaian dan evaluasi. Tahap penyesuaian memiliki beberapa langkah yaitu membuat Activity Relationship Chart (ARC), Activity Relationship Diagram (ARD), penentuan luas area yang dibutuhkan, dan membuat tiga alternatif perbaikan dari tata letak fasilitas produksi yang ada. ARC disimbolkan dengan huruf $\mathrm{A}, \mathrm{E}, \mathrm{I}, \mathrm{O}, \mathrm{U}$, dan $\mathrm{X}$. Huruf-huruf tersebut menunjukkan tingkat kepentingan mulai dari aktivitas yang mutlak penting hingga aktivitas yang tidak diinginkan. ARD merupakan analisis aliran material setelah ARC yang membuat visualisasi aliran material dan hubungan aktivitas antar stasiun kerja yang lebih jelas. Sedangkan penentuan luas area yang dibutuhkan ditentukan dengan mempertimbangkan luas mesin dan peralatan, serta space untuk operator. Kelonggaran untuk operator sebanyak $15 \%$. Kelonggaran yang diberikan pada tiap mesin sebesar 0,75 meter - 1 meter berdasarkan metode fasilitas industri (Purnomo, 2004). Kemudian perancangan tata letak usulan dibuat berdasarkan pengolahan data sebelumnya. Sedangkan tahap evaluasi bertujuan untuk melakukan pemilihan terhadap tiga alternatif tata letak fasilitas yang telah dirancang.

\section{HASIL DAN PEMBAHASAN}

\subsection{Frekuensi Perpindahan Bahan Antar Area Kerja}

Penentuan frekuensi perpindahan bahan diperoleh berdasarkan observasi langsung pada proses produksi plastik polyethylene kecil di PT. Pilar Kekar plasindo. Tata letak fasilitas awal dengan skala 1:100 ditunjukkan pada Gambar 1 dan frekuensi perpindahan bahan pada produksi polyethylene kecil ditunjukkan pada Tabel 1. 


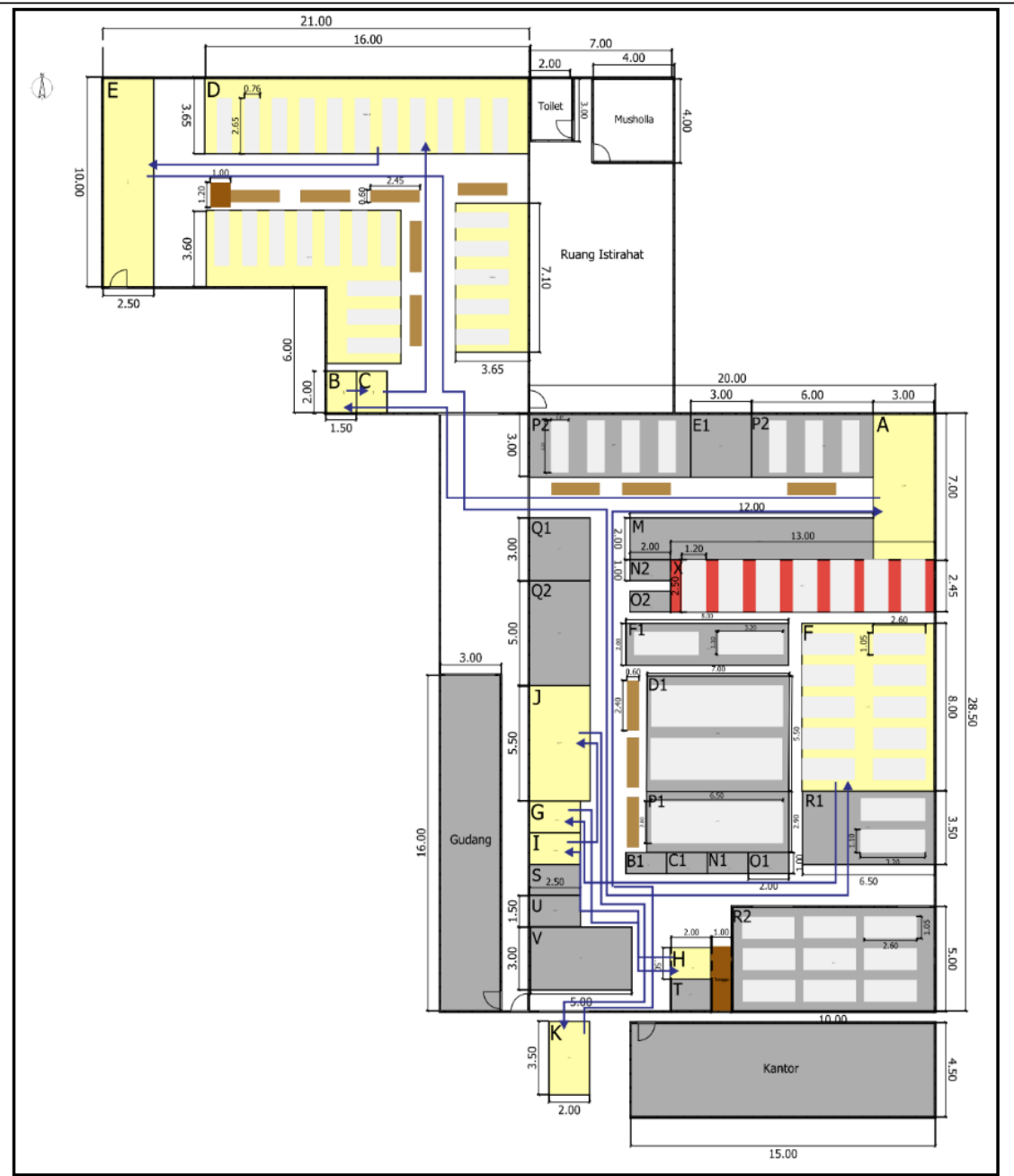

Gambar 1 Tata Letak Fasilitas Awal

Tabel 1 Frekuensi Perpindahan Bahan Antar Area Kerja

\begin{tabular}{|c|c|c|c|c|c|c|c|}
\hline No & $\begin{array}{c}\text { Jenis } \\
\text { Aktivitas }\end{array}$ & $\begin{array}{c}\text { Alat } \\
\text { Angkut }\end{array}$ & $\begin{array}{l}\text { Total } \\
\text { Aktivitas } \\
\text { per Hari } \\
\text { (Unit) } \\
\text { (d) }\end{array}$ & $\begin{array}{l}\text { Kapasitas } \\
\text { Material } \\
\text { Handling } \\
\text { (Unit) (e) }\end{array}$ & $\begin{array}{c}\text { Total } \\
\text { Material } \\
\text { Handling per } \\
\text { Hari } \\
(\mathrm{f})=(\mathrm{d}) /(\mathrm{e})\end{array}$ & $\begin{array}{c}\text { Frekuensi } \\
(\mathrm{g})=(\mathrm{f}) \mathrm{x} \\
24 \text { hari }\end{array}$ & $\begin{array}{l}\text { Urutan } \\
\text { Proses }\end{array}$ \\
\hline 1 & $\begin{array}{c}\text { Pengambilan } \\
\text { bahan baku }\end{array}$ & Troli & 96 & 6 & 16 & 384 & $\mathrm{~K}, \mathrm{~A}$ \\
\hline 2 & $\begin{array}{c}\text { Pencampuran } \\
\text { bahan baku }\end{array}$ & Troli & 192 & 6 & 32 & 768 & A, B \\
\hline 3 & $\begin{array}{l}\text { Pemanasan } \\
\text { bahan baku }\end{array}$ & Manusia & 192 & 1 & 192 & 4608 & $\mathrm{~B}, \mathrm{C}$ \\
\hline 4 & $\begin{array}{l}\text { Pembuatan } \\
\text { plastik rol }\end{array}$ & Troli & 192 & 6 & 32 & 768 & $\mathrm{C}, \mathrm{D}$ \\
\hline 5 & $\begin{array}{l}\text { Penyimpanan } \\
\text { produk } \\
\text { setengah jadi }\end{array}$ & Troli & 192 & 6 & 32 & 768 & $\mathrm{D}, \mathrm{E}$ \\
\hline 6 & $\begin{array}{l}\text { Pemotongan } \\
\text { plastik }\end{array}$ & Troli & 192 & 6 & 32 & 768 & $\mathrm{E}, \mathrm{F}$ \\
\hline 7 & Inspeksi & Troli & 192 & 6 & 32 & 768 & $\mathrm{~F}, \mathrm{G}$ \\
\hline
\end{tabular}


TEKINFO - Jurnal IImiah Teknik Industri dan Informasi

Vol. 9 - No. 1 (November 2020)

\begin{tabular}{|c|c|c|c|c|c|c|c|}
\hline No & $\begin{array}{c}\text { Jenis } \\
\text { Aktivitas }\end{array}$ & $\begin{array}{c}\text { Alat } \\
\text { Angkut }\end{array}$ & $\begin{array}{l}\text { Total } \\
\text { Aktivitas } \\
\text { per Hari } \\
\text { (Unit) } \\
\text { (d) }\end{array}$ & $\begin{array}{l}\text { Kapasitas } \\
\text { Material } \\
\text { Handling } \\
\text { (Unit) (e) }\end{array}$ & $\begin{array}{c}\text { Total } \\
\text { Material } \\
\text { Handling per } \\
\text { Hari } \\
\text { (f) }=(\mathrm{d}) /(\mathrm{e})\end{array}$ & $\begin{array}{c}\text { Frekuensi } \\
(\mathrm{g})=(\mathrm{f}) \mathrm{x} \\
24 \text { hari }\end{array}$ & $\begin{array}{l}\text { Urutan } \\
\text { Proses }\end{array}$ \\
\hline 8 & Penjahitan & Manusia & 192 & 1 & 192 & 4608 & $\mathrm{G}, \mathrm{H}$ \\
\hline 9 & Pengemasan & Manusia & 192 & 1 & 192 & 4608 & $\mathrm{H}, \mathrm{I}$ \\
\hline 10 & $\begin{array}{c}\text { Penyimpanan } \\
\text { produk jadi }\end{array}$ & Troli & 192 & 6 & 32 & 768 & $\mathrm{I}, \mathrm{J}$ \\
\hline 11 & $\begin{array}{l}\text { Pengiriman } \\
\text { produk jadi }\end{array}$ & Troli & 96 & 6 & 16 & 384 & $\mathrm{~J}, \mathrm{~K}$ \\
\hline
\end{tabular}

\subsection{Penentuan Jarak Perpindahan Material Menggunakan Jarak Rectilinear}

Penentuan jarak perpindahan bahan antar stasiun kerja dapat dihitung dengan menggunakan jarak Rectilinear. Jarak Rectilinear merupakan jarak yang diukur mengikuti jalur tegak lurus. Total jarak perpindahan pada produksi polyethylene kecil adalah 229 meter.

\subsection{Ongkos Material Handling Awal}

Ongkos material handling pada produksi plastik polyethylene kecil dibagi menjadi dua, yaitu ongkos dengan tenaga manusia dan ongkos dengan bantuan troli. Total ongkos material handling pada produksi plastik polyethylene kecil ditunjukkan pada Tabel 2.

Tabel 2 Ongkos Material Handling Awal

\begin{tabular}{|c|c|c|c|c|c|c|c|c|c|c|}
\hline Dari & $\mathrm{Ke}$ & Komponen & $\begin{array}{c}\text { Alat } \\
\text { Angkut }\end{array}$ & $\begin{array}{l}\text { Frekuen } \\
\text { si }(\mathrm{g})\end{array}$ & $\begin{array}{l}\text { Jarak } \\
(\mathrm{m}) \\
(\mathrm{h})\end{array}$ & $\begin{array}{c}\text { Total } \\
\text { Jarak }(\mathrm{m}) \\
(\mathrm{i})=(\mathrm{g}) \mathrm{x}(\mathrm{h} \\
)\end{array}$ & $\begin{array}{l}\text { Waktu } \\
\text { perpin } \\
\text { dahan } \\
\text { (s) (j) }\end{array}$ & $\begin{array}{l}\text { Total Waktu } \\
\text { Perpindahan } \\
\text { (s) } \\
(\mathrm{k})=(\mathrm{j}) \times(\mathrm{g})\end{array}$ & $\begin{array}{l}\text { OMH/ } \\
\text { meter } \\
(\mathrm{Rp}) \\
(1)\end{array}$ & $\begin{array}{l}\text { Tot OMH / } \\
\text { bulan (Rp) } \\
(\mathrm{m})=(\mathrm{i}) \mathrm{x}(\mathrm{l})\end{array}$ \\
\hline K & $\mathrm{A}$ & $\begin{array}{c}\text { Bijih } \\
\text { Plastik }\end{array}$ & Troli & 384 & 40,75 & 15.648 & 82 & 31.488 & 170 & 2.654 .481 \\
\hline A & B & $\begin{array}{c}\text { Bijih } \\
\text { Plastik }\end{array}$ & Troli & 768 & 32,25 & 24.768 & 71 & 54.528 & 170 & 4.201 .571 \\
\hline B & $\mathrm{C}$ & $\begin{array}{l}\text { Bijih } \\
\text { Plastik }\end{array}$ & Manusia & 4.608 & 1,50 & 6.912 & 5 & 23.040 & 123 & 849.563 \\
\hline $\mathrm{C}$ & $\mathrm{D}$ & $\begin{array}{c}\text { Bijih } \\
\text { Plastik }\end{array}$ & Troli & 768 & 13,50 & 10.368 & 32 & 24.576 & 170 & 1.758 .797 \\
\hline D & $\mathrm{E}$ & Plastik Roll & Troli & 768 & 15 & 11.520 & 36 & 27.648 & 170 & 1.954 .219 \\
\hline E & F & Plastik Roll & Troli & 768 & 61,50 & 47.232 & 110 & 84.480 & 170 & 8.012 .297 \\
\hline $\mathrm{F}$ & $\mathrm{G}$ & $\begin{array}{l}\text { Plastik } \\
\text { Potong }\end{array}$ & Troli & 768 & 20,75 & 15.936 & 48 & 36.864 & 170 & 2.703 .336 \\
\hline G & $\mathrm{H}$ & $\begin{array}{l}\text { Plastik } \\
\text { Potong }\end{array}$ & Manusia & 4.608 & 13,75 & 63.360 & 26 & 119.808 & 132 & 7.787 .664 \\
\hline $\mathrm{H}$ & I & Produk Jadi & Manusia & 4.608 & 12,25 & 56.448 & 23 & 105.984 & 123 & 6.938 .101 \\
\hline I & $\mathrm{J}$ & Produk Jadi & Troli & 768 & 5,25 & 4.032 & 21 & 16.128 & 170 & 683.977 \\
\hline \multirow[t]{2}{*}{$\mathrm{J}$} & $\mathrm{K}$ & Produk Jadi & Troli & 384 & 12,50 & 4.800 & 25 & 9.600 & 170 & 814.258 \\
\hline & & & $\Sigma$ & 19.200 & 229 & 261.024 & 479 & 534.144 & 1.726 & 38.358 .263 \\
\hline
\end{tabular}


3.4 Inflow

Perhitungan inflow dibuat berdasarkan From To chart. Inflow menunjukkan koefisien atas ongkos pada From To chart dilihat dari ongkos yang masuk ke suatu mesin. Koefisien inflow ditunjukkan pada Tabel 3.

Tabel 3 Inflow

\begin{tabular}{ccccccccccccc} 
To & K & A & B & C & D & E & F & G & H & I & J & $\begin{array}{c}\text { Total } \\
\text { From }\end{array}$ \\
\hline K & & 1 & & & & & & & & & & 1 \\
A & & & 1 & & & & & & & & \\
B & & & & 1 & & & & & & & \\
C & & & & & 1 & & & & & & \\
D & & & & & & 1 & & & & & \\
E & & & & & & & 1 & & & & & 1 \\
F & & & & & & & & 1 & & & & 1 \\
G & & & & & & & & & 1 & & & 1 \\
H & & & & & & & & & & 1 & & 1 \\
I & & & & & & & & & & & 1 & 1 \\
J & 1 & & & & & & & & & & & 1 \\
Total & 1 & 1 & 1 & 1 & 1 & 1 & 1 & 1 & 1 & 1 & 1 & 1 \\
OMH & 1 & 1 & 1 & 1 & & & 1 \\
\hline
\end{tabular}

\subsection{Tabel Skala Prioritas}

Tabel skala prioritas diperoleh dari hasil perhitungan inflow. Prioritas diurutkan berdasarkan harga koefisien ongkos dimana nilai koefisien terbesar ditempatkan pada prioritas pertama. Tabel Skala Prioritas dapat dilihat pada Tabel 4.

Table 4 Tabel Skala Prioritas

\begin{tabular}{ccccc}
\hline \multirow{2}{*}{ No } & \multirow{2}{*}{ Area Kerja } & Kode & \multicolumn{2}{c}{ Prioritas } \\
\cline { 4 - 5 } & & $\mathrm{I}$ & II \\
\hline 1 & Area Bahan Baku PE Kecil & $\mathrm{A}$ & $\mathrm{B}$ \\
2 & Area Pencampuran Bahan PE Kecil & $\mathrm{B}$ & $\mathrm{C}$ \\
3 & Area Pemanasan Bahan PE Kecil & $\mathrm{C}$ & $\mathrm{D}$ \\
4 & Area Pembuatan Plastik Rol PE Kecil & $\mathrm{D}$ & $\mathrm{E}$ \\
5 & Area Bahan Sementara PE Kecil & $\mathrm{E}$ & $\mathrm{F}$ \\
6 & Area Pemotongan PE Kecil & $\mathrm{F}$ & $\mathrm{G}$ \\
7 & Area Inspeksi PE Kecil & $\mathrm{G}$ & $\mathrm{H}$ \\
8 & Area Penjahitan PE Kecil & $\mathrm{H}$ & $\mathrm{I}$ \\
9 & Area Pengemasan PE Kecil & $\mathrm{I}$ & $\mathrm{J}$ \\
10 & Area Produk Jadi PE Kecil & $\mathrm{J}$ & $\mathrm{K}$ \\
11 & Area Bongkar Muat & $\mathrm{K}$ & $\mathrm{A}$ \\
\hline
\end{tabular}

\subsection{Activity Relationship Chart (ARC)}

Tahap selanjutnya adalah pembuatan Activity Relationship Chart (ARC). ARC disusun berdasarkan tingkat kepentingan hubungan antar aktivitas dan masingmasing memiliki alasan kedekatan. Pembuatan ARC mempertimbangkan tabel skala prioritas. ARC pada produksi polyethylene kecil ditunjukkan pada Gambar 2. 


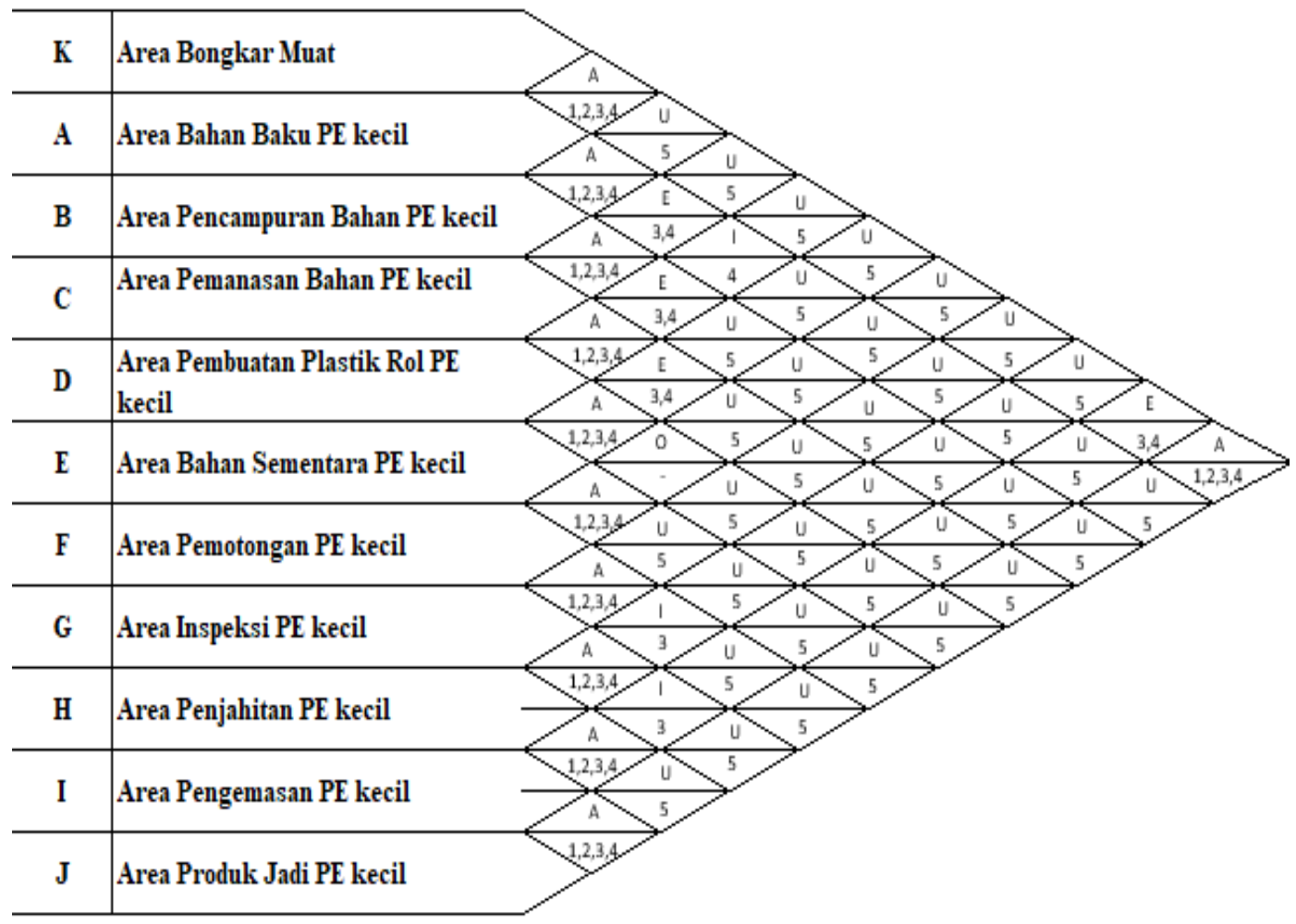

Gambar 2 Activity Relationship Chart

\subsection{Penentuan Luas Area yang Dibutuhkan}

Penentuan luas area yang dibutuhkan bertujuan untuk merancang tata letak fasilitas usulan yang disesuaikan dengan kebutuhan kegiatan produksi. Tiga hal yang dapat dijadikan sebagai dasar penentuan luas area yaitu tingkat produksi, peralatan yang dibutuhkan, dan karyawan yang bekerja pada area tersebut. Luas area yang dibutuhkan pada produksi polyethylene kecil ditunjukkan pada Tabel 5.

Tabel 5 Luas Area yang Dibutuhkan pada Area Produksi Plastik Polyethylene Kecil

\begin{tabular}{|c|c|c|c|c|c|c|c|c|}
\hline \multirow[b]{2}{*}{ No } & \multirow[b]{2}{*}{ Area Aktivitas } & \multirow[b]{2}{*}{$\begin{array}{l}\text { Mesin atau } \\
\text { Material }\end{array}$} & \multirow[b]{2}{*}{$\begin{array}{l}\text { Jumlah } \\
\text { (m) }\end{array}$} & \multicolumn{2}{|c|}{ Mesin + Toleransi } & \multirow[b]{2}{*}{$\begin{array}{l}\text { Luas }(L)= \\
(m) x(a) x(b)\end{array}$} & \multirow[b]{2}{*}{$\begin{array}{c}\text { Allowance } \\
(15 \%)\end{array}$} & \multirow[b]{2}{*}{$\begin{array}{c}\text { Kebutuhan } \\
\text { Ruangan } \\
(\mathrm{N})= \\
(\mathrm{L})+(\mathrm{c})\end{array}$} \\
\hline & & & & $\begin{array}{c}\text { Panjang } \\
+ \\
\text { Toleransi } \\
=(a)\end{array}$ & $\begin{array}{l}\text { Lebar }+ \\
\text { Toleransi } \\
=(b)\end{array}$ & & & \\
\hline 1 & $\begin{array}{c}\text { Area Bahan } \\
\text { Baku PE }\end{array}$ & Bijih Plastik & 24 & & & 7,02 & 1,053 & 8,073 \\
\hline 2 & $\begin{array}{c}\text { Area } \\
\text { Pencampuran } \\
\text { Bahan PE }\end{array}$ & $\begin{array}{c}\text { Mesin } \\
\text { Pencampur }\end{array}$ & 1 & 2,75 & 2,25 & 6,1875 & 0,928125 & 7,115625 \\
\hline 3 & $\begin{array}{c}\text { Area } \\
\text { Pemanasan } \\
\text { Bahan PE }\end{array}$ & $\begin{array}{l}\text { Mesin } \\
\text { Pemanas }\end{array}$ & 1 & 2,75 & 2,25 & 6,1875 & 0,928125 & 7,115625 \\
\hline 4 & $\begin{array}{l}\text { Area Pembuatan } \\
\text { Plastik Rol PE }\end{array}$ & $\begin{array}{c}\text { Mesin } \\
\text { Pembuat } \\
\text { Plastik Rol } \\
\text { Meja }\end{array}$ & 26 & 3,4 & 1,5 & 132,6 & 23,778 & 182,298 \\
\hline 5 & $\begin{array}{c}\text { Area Bahan } \\
\text { Sementara PE }\end{array}$ & Plastik Rol & 32 & 0 & 0 & 9,36 & 1,404 & 10,764 \\
\hline 6 & Area & $\begin{array}{c}\text { Mesin } \\
\text { Pemotong }\end{array}$ & 10 & 3,05 & 1,8 & 54,9 & 9,9675 & 76,4175 \\
\hline
\end{tabular}




\begin{tabular}{|c|c|c|c|c|c|c|c|c|}
\hline \multirow[b]{2}{*}{ No } & \multirow[b]{2}{*}{ Area Aktivitas } & \multirow[b]{2}{*}{$\begin{array}{l}\text { Mesin atau } \\
\text { Material }\end{array}$} & \multirow[b]{2}{*}{$\begin{array}{l}\text { Jumlah } \\
(\mathrm{m})\end{array}$} & \multicolumn{2}{|c|}{ Mesin + Toleransi } & \multirow[b]{2}{*}{$\begin{array}{l}\text { Luas }(L)= \\
(m) x(a) x(b)\end{array}$} & \multirow[b]{2}{*}{$\begin{array}{c}\text { Allowance } \\
(15 \%)\end{array}$} & \multirow[b]{2}{*}{$\begin{array}{c}\text { Kebutuhan } \\
\text { Ruangan } \\
(\mathrm{N})= \\
(\mathrm{L})+(\mathrm{c})\end{array}$} \\
\hline & & & & $\begin{array}{c}\text { Panjang } \\
+ \\
\text { Toleransi } \\
=(a)\end{array}$ & $\begin{array}{l}\text { Lebar }+ \\
\text { Toleransi } \\
=(\mathrm{b})\end{array}$ & & & \\
\hline & Pemotongan PE & Plastik & & & & & & \\
\hline & & $\begin{array}{l}\text { Timbangan } \\
\text { Digital Mini }\end{array}$ & 10 & 1,1 & 1,05 & 11,55 & & \\
\hline 7 & $\begin{array}{c}\text { Area Inspeksi } \\
\text { PE }\end{array}$ & $\begin{array}{l}\text { Timbangan } \\
\text { Digital Besar }\end{array}$ & 2 & 1,55 & 1,4 & 4,34 & 0,651 & 4,991 \\
\hline 8 & $\begin{array}{c}\text { Area Penjahitan } \\
\text { PE }\end{array}$ & Mesin Jahit & 2 & 1,65 & 1,15 & 3,795 & 0,56925 & 4,36425 \\
\hline 9 & $\begin{array}{c}\text { Area } \\
\text { Pengemasan PE }\end{array}$ & $\begin{array}{l}\text { Mesin } \\
\text { Packing }\end{array}$ & 2 & 1,65 & 1,35 & 4,455 & 0,66825 & 5,12325 \\
\hline 10 & $\begin{array}{l}\text { Area Produk } \\
\text { Jadi PE }\end{array}$ & Produk Jadi & 24 & 0 & 0 & 7,02 & 1,053 & 8,073 \\
\hline 11 & $\begin{array}{c}\text { Area Bongkar } \\
\text { Muat }\end{array}$ & Truk & 1 & 4,25 & 2,75 & 11,6875 & 1,753125 & 13,440625 \\
\hline & & & $\Sigma$ & & & & & 327,775875 \\
\hline
\end{tabular}

\subsection{Perancangan Tata Letak Fasilitas Usulan}

Perancangan tata letak fasilitas yang diusulkan memiliki pola aliran bahan berbentuk circular. Perbaikan yang dilakukan yaitu memindahkan mesin yang rusak ke gudang, mengatur mesin, alat, dan stasiun kerja sesuai dengan hasil produk jadi dan berdasarkan urutan prosesnya. Jarak perpindahan material dan ongkos material handling pada ketiga alternatif perbaikan diperoleh. Hasil total jarak perpindahan material dari usulan 1 adalah 98 meter. Total jarak perpindahan bahan dari usulan 1 lebih pendek 131 meter atau lebih pendek $57 \%$ dibanding tata letak fasilitas awal. Total OMH perbulan dari usulan 1 yaitu Rp 13.498.656,00 yang berkurang sebesar Rp 24.859.607,00 atau sebesar 64\%. Hasil total jarak perpindahan material dari usulan 2 adalah 92,5 meter. Total jarak perpindahan bahan dari usulan 2 lebih pendek 136,5 meter atau lebih pendek 59,6\% dibanding tata letak fasilitas awal. Total OMH perbulan dari usulan 2 yaitu $\mathrm{Rp} 12.163 .273,00$ yang berkurang sebesar Rp 26.194.990,00 atau sebesar 68,3\%. Sedangkan hasil total jarak perpindahan material dari usulan 3 adalah 92,5 meter. Total jarak perpindahan bahan dari usulan 3 lebih pendek 136,5 meter atau lebih pendek 59,6\% dibanding tata letak fasilitas awal. Total $\mathrm{OMH}$ perbulan dari usulan 3 yaitu Rp 12.716.968,00 yang berkurang sebesar Rp 25.641.295,00 atau sebesar 66,8\%. Tata letak fasilitas usulan 1, 2, dan 3 ditunjukkan pada Gambar 3, 4, dan 5 secara berurutan. 


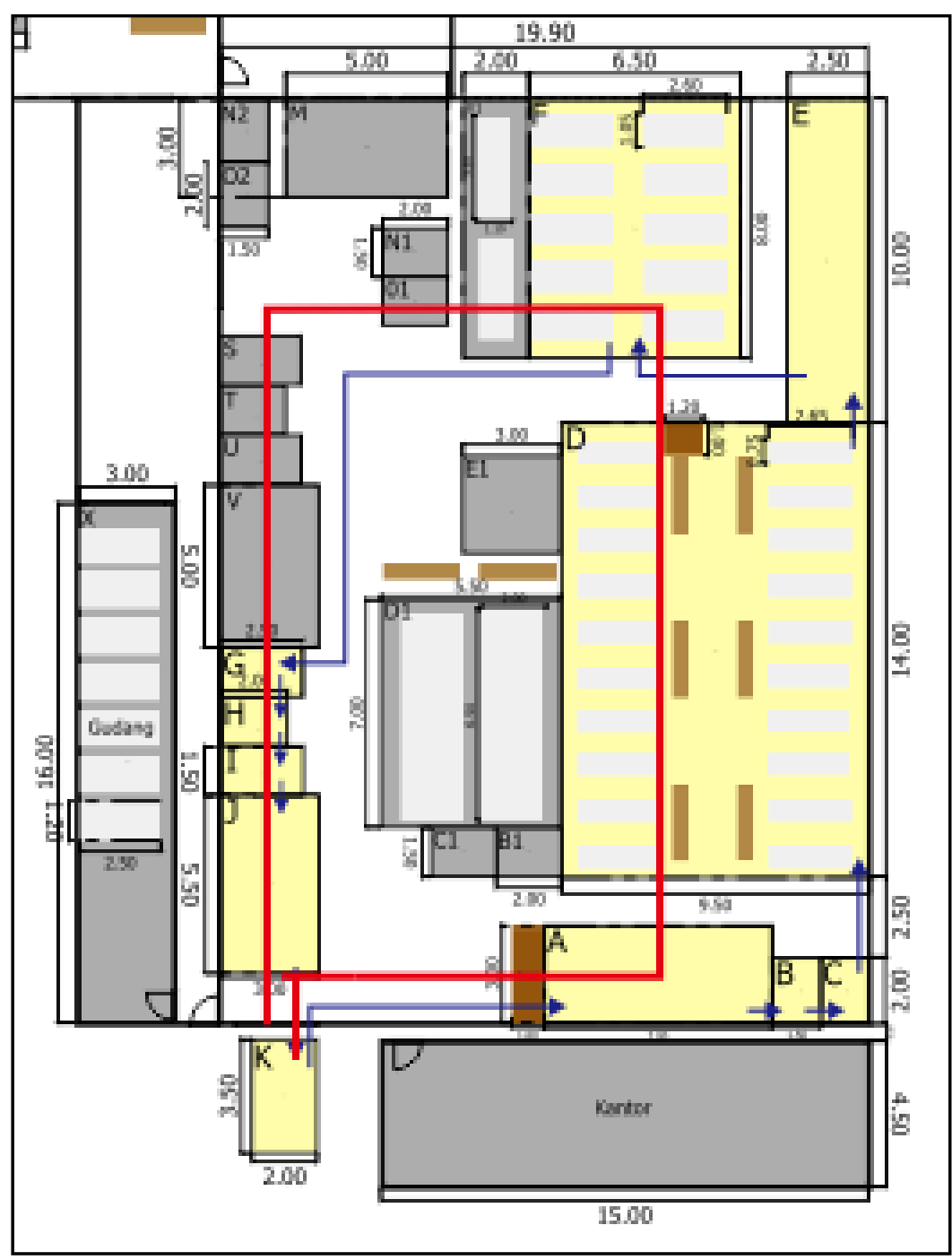

Gambar 3 Tata Letak Fasilitas Usulan 1 


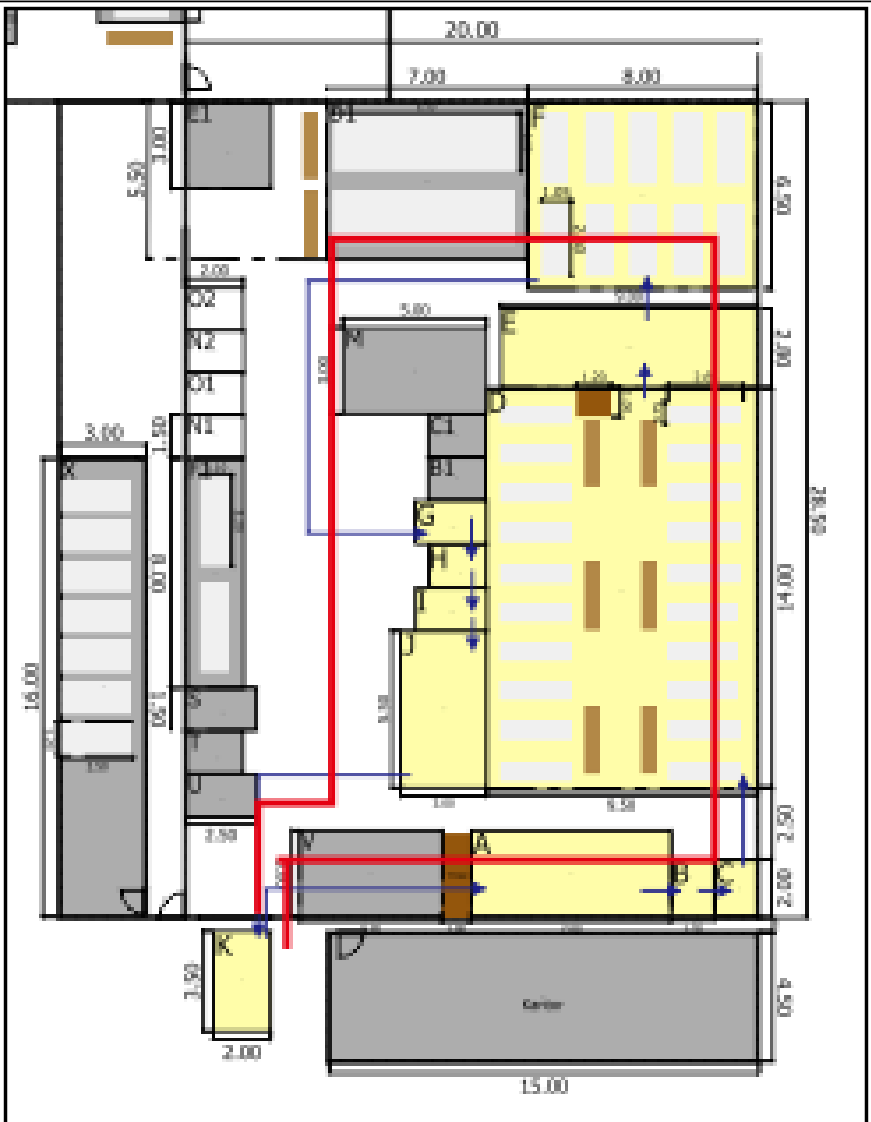

Gambar 4 Tata Letak Fasilitas Usulan 2

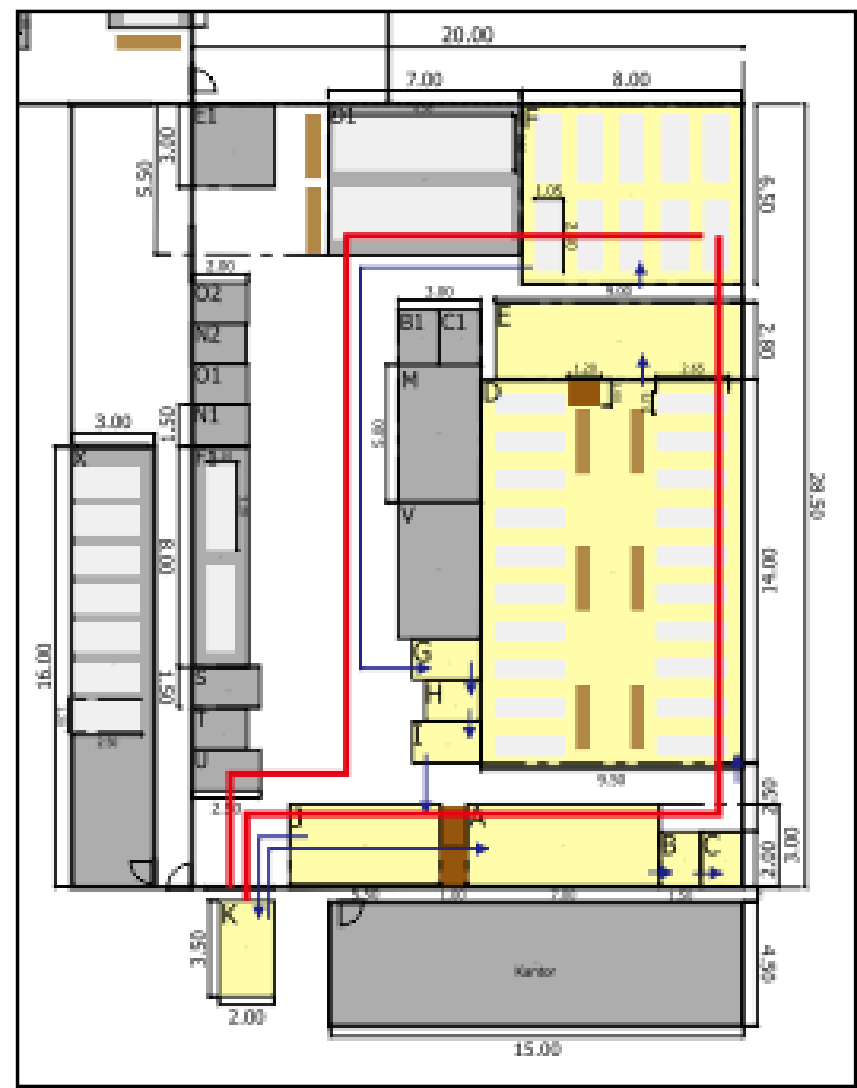

Gambar 5 Tata Letak Fasilitas Usulan 3 
Berdasarkan hasil perhitungan, maka tata letak fasilitas yang dipilih yaitu tata letak fasilitas usulan kedua karena mampu mengurangi total biaya perpindahan material sebesar $68,3 \%$ dan mengurangi jarak perpindahan material sebesar sebesar $59,6 \%$ dari tata letak fasilitas awal. Jumlah persentase ini adalah yang terbesar diantara kedua alternatif usulan lainnya.

\section{KESIMPULAN}

Pada penelitian ini dilakukan peningkatan tata letak fasilitas pada produksi polyethylene kecil di PT. Pilar Kekar Plasindo menggunakan metode Systematic Layout Planning. Tiga alternatif usulan rancangan tata letak dibuat pada penelitian ini dan didapatkan bahwa alternatif tata letak fasilitas kedua memiliki kinerja yang lebih baik dibandingkan dengan usulan pertama dan ketiga. Tata letak fasilitas usulan kedua dipilih karena memiliki jarak dan ongkos material handling yang paling kecil dibandingkan dengan tata letak fasilitas usulan lainnya. Tata letak fasilitas usulan kedua juga dapat menghilangkan back tracking dan mengurangi cross movement.

\section{DAFTAR PUSTAKA}

Kustriyanto, E., Pambuditama, I. and Irawan, Y. S. (2016) 'Perbaikan Layout Mesin Produksi Longsong Munisi Menggunakan Metode Systematic Layout Planning dan Blocplan (Studi Kasus: Divisi Munisi - PT. Pindad (Persero))', Jurnal Rekayasa Mesin, 7(3), pp. 103-112. doi: 10.21776/ub.jrm.2016.007.03.1.

Muslim, D. and Ilmaniati, A. (2018) 'Usulan Perbaikan Tata Letak Fasilitas Terhadap Optimalisasi Jarak dan Ongkos Material Handling Dengan Pendekatan Systematic layout Planning (SLP) di PT Transplant Indonesia', Jurnal Media Teknik dan Sistem Industri, 2(1), pp. 45-52. doi: 10.35194/jmtsi.v2i1.327.

Naganingrum, R. P., Jauhari, W. A. and Herdiman, L. (2013) 'Perancangan Ulang Tata Letak Fasilitas di PT. Dwi Komala dengan Metode Systematic Layout Planning', Performa, 12(1), pp. 39-50.

Paillin, D. B. (2013) 'Usulan Perbaikan Tata Letak Lantai Produksi Menggunakan Algoritma CRAFT dalam Meminimumkan Ongkos Material Handling dan Total Momen Jarak Perpindahan (Studi Kasus PT. Grand Kartect Jakarta)', Metris, 14, pp. 73-82.

Pangestika, J. W., Handayani, N. and Kholil, M. (2016) 'Usulan Re-Layout Tata Letak Fasilitas Produksi Dengan Menggunakan Metode SLP Di Departemen Produksi Bagian OT Cair Pada PT IKP', JISI: Jurnal Integrasi Sistem Industri, 3(1), pp. 29-38. doi: 10.24853/jisi.4.1.pp-pp.

Purnomo, H. (2004) Perencanaan dan Perancangan Fasilitas. Yogyakarta: Graha Ilmu.

Sofyan, D. K. and Syarifuddin, S. (2015) 'Perancangan Ulang Tata Letak Fasilitas dengan Menggunakan Metode Konvensional Berbasis 5S (Seiri, Seiton, Seiso, Seiketsu dan Shitsuke)', Jurnal Teknovasi, 2(2), pp. 27-41. 
Starbek, M. and Menart, D. (2000) 'The Optimization of Material Flow Production', International Journal of Machine Tools \& Manufacture, 40, pp. 1299-1310.

Stephens, M. P. (2010) Manufacturing Facilities Design and Material Handling. New Jersey: Pearson Education.

Suhardi, B., Juwita, E. and Astuti, R. D. (2019) 'Facility Layout Improvement in Sewing Department with Systematic Layout Planning and Ergonomics Approach', Cogent Engineering, 6(1), pp. 1-21. doi: 10.1080/23311916.2019.1597412.

Tompkins, J. . et al. (2010) Facilities Planning. 4th edn. California: John Wiley \& Sons, Inc.

Wignjosoebroto, S. (2003) Tata Letak Pabrik dan Pemindahan Bahan. 3rd edn. Surabaya: Guna Widya. 